\title{
Physico-Chemical Characterization and Microbial Studies of Muscle Lipid of Liner Silver Grunter (Pomadasys hasta) of the Bay of Bengal
}

\author{
Farjana Jahan $^{1, a}$, M. Helal Uddin ${ }^{2, b^{*}}$, Sreebash C. Bhattacharjee ${ }^{3, c}$ \\ ${ }^{1}$ Department of Allied Sciences, Faculty of Science, Engineering and Technology, \\ University of Science and Technology Chittagong (USTC), Chittagong, Bangladesh \\ ${ }^{2}$ Department of Applied \& Environmental Chemistry, University of Chittagong, \\ Chittagong 4331, Bangladesh
${ }^{3}$ Bangladesh Council of Scientific and Industrial Research (BCSIR), Chittagong, Bangladesh
afjahanjini@gmail.com, ㅎmhuddincu@yahoo.com, 'sreebash2008@gmail.com

Keywords: Pomadasys hasta, lipid, physico-chemical, TLC, GLC, metal analysis, microbial, study, polyunsaturated fatty acid.

\begin{abstract}
Lipid was extracted from the lipid containing muscle of Liner silver grunter (Pomadasys hasta) by solvent extraction and then purified by standard method. The physico-chemical properties of lipid sample were determined and compared with those of other standard fats and oils. Fatty acid composition of the lipid sample was investigated by Thin Layer Chromatographic (TLC) examination. Gas Liquid Chromatographic (GLC) examination was performed by the methyl esters mixture prepared from the lipid sample. The de-oiled muscle of the fish was studied for the determination of ash content, fiber content, moisture content and protein content. The lipid containing selected muscle was analyzed quantitatively for the determination of percentages of protein, cholesterol and minerals $(\mathrm{N}, \mathrm{P}, \mathrm{K}, \mathrm{Ca}$, and $\mathrm{Na}$ ). The lipid containing muscle was also analyzed for the determination of the amount of eleven metals by using Atomic Absorption Spectrophotometric method. The lipid sample was evaluated by microbial activity (bacterial activity against nine bacteria and fungal activity against seven fungi).
\end{abstract}

\section{Introduction}

Bangladesh is a land of rivers and southern part of which is completely covered by the Bay of Bengal. Most of the peoples in the developing countries like Bangladesh are dependent on fish as a source of animal protein and about $80 \%$ of the animal protein in our diet comes from fish alone [1]. Liner silver grunter, locally known as Datina Koral, constitutes an important part of the fishery resources of Bangladesh. It is a valuable natural resource of Bangladesh. Currently, the biochemical effects of fish oils in human health and nutrition [2,3] have placed renewed emphasis on the apparent difference in the compositions of fish oils [4]. In the present study, the lipid of the muscle of liner silver grunter (Pomadasys hasta or Pomadasys argenteus (Forsskål, 1775)) was analyzed so as to explore the possibilities of commercial exploitation of this highly available species as a source of marine oils and polyunsaturated fatty acids of $\omega-3$ series.

The lipid sample was also evaluated in terms of biological activities (bacterial and fungal activities) for pharmacological aspects. It is to be noted here that fish lipids contain highly unsaturated fatty acids which reduce the cholesterol and LDL (low density lipoprotein) blamed for causing heart disease. The fish lipids also increase the level of HDL (high density lipoprotein) known as a friendly cholesterol for its role in cleaning LDL deposited in blood vessels [5]. Liner silver grunter may also contain pharmaceutically important and physiologically active essential fatty acid ( $\omega-3$ and other PUFA) in their body. Liner silver grunter is juveniles brilliant silvery with 12 or more faint vertical bars. The adults are uniformly green above and silvery below [6]. 


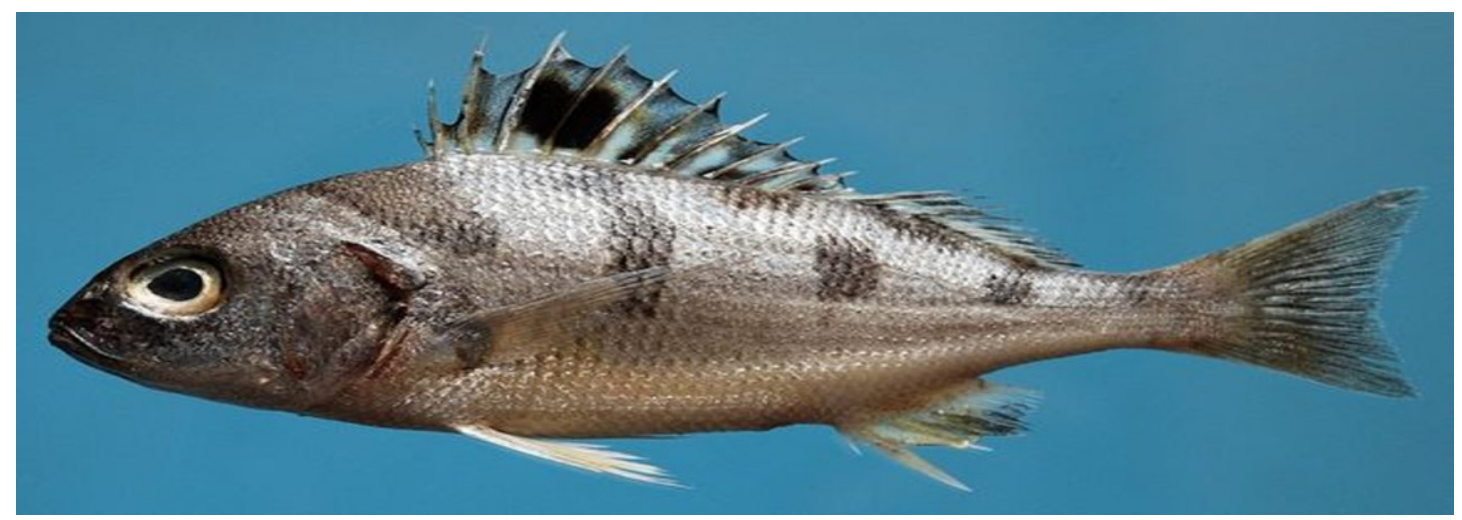

Figure 1. Liner silver grunter (Pomadasys hasta)

\section{Experimental}

Liner silver grunter (Pomadasys hasta) was collected from the local fish market and identified in the Institute of Marine Sciences and Fisheries, University of Chittagong as well as in the Department of Zoology, University of Chittagong. Oil extraction from the muscle was carried out by solvent extraction method using acetone and ethyl acetate as solvent. Combined extract was recovered with a rotary evaporator at $45{ }^{\circ} \mathrm{C}$ to obtain lipid and dried under flushing with a slow stream of nitrogen gas for the removal of residual solvent. Analytical grade chemicals were used and solutions were prepared according to the standard procedure [7-9]. The amount of total lipid was determined gravimetrically. Crude fibre and ash content of the muscle of liner silver grunter were determined by standard methods [10]. A weight portion of the lipid containing muscle of liner silver grunter was first dried in an oven at about $100-105{ }^{\circ} \mathrm{C}$ for $4-5$ hours to remove moisture and then burnt into ash in a muffle furnace at about $600{ }^{\circ} \mathrm{C}$ for 4 hours [11].

Saponification value, saponification equivalent value, acid value and percentage of free fatty acid (as oleic acid), iodine value, acetyl value [12], peroxide value [13], thiocyanogen value, Richert- Meissl value, Polenske value [14], Henher value, Kirschner value, Elaiden test [15] and quantity of unsaponifiable matter [16] of the lipid sample were determined by standard methods. Thin layer chromatographic (TLC) investigation of the fatty acids present in the lipid sample was carried out in various solvent systems [17].

The identification of fatty acid components from GLC analysis was carried out on the basis of relative retention time and was quantified by measuring the peak area in comparison with standard value [18]. Cholesterol of the sample was determined with the standard method [19]. By applying standard methods, percentages of minerals $(\mathrm{N}, \mathrm{P}, \mathrm{K}, \mathrm{Ca}$ and $\mathrm{Na}$ ) of lipid containing muscle were determined [20]. For analysis of metal contents of the muscle, the sample solution was prepared by using wet-digestion method and was stored in a refrigerator until analysis. An exactly similar blank solution of $100 \mathrm{ml}$ was prepared for the test. For determining the presence and amount of metals in the sample, an Atomic Absorption Flame Emission Spectrophotometer (Thermoscientific ICE 3000 series) was used [21,22]. For antibacterial activities, the disc diffusion method was followed and the antifungal activity was assessed by food poison technique [23].

\section{Results and Discussion}

\subsection{Physical characteristics}

The refractive index of the muscle lipid of liner silver grunter was found to be 1.4855 at $30{ }^{\circ} \mathrm{C}$. The refractive power of oils or fat varies widely and chiefly governed by the proportion and degree of unsaturation present. It is thus characteristic of various classes of fats or oils and is extensively used in butter analysis. The present result indicates that the muscle lipid from the specimen contained moderate amount of unsaturated fatty acids.

The specific gravity of the lipid solution of the muscle lipid of liner silver grunter was found to be 0.934 at $30{ }^{\circ} \mathrm{C}$. 
The viscosity of the lipid solution of the muscle lipid of liner silver grunter was found to be 297.112 milipoise at $30{ }^{\circ} \mathrm{C}$ with the help of Ostwald's viscometer. The energy of activation for viscous flow was also calculated and found to be $5.693 \mathrm{Kcal}$. From the result of this experiment, we got an idea about the intermolecular hydrogen bonding in the lipid sample. The present result suggests that there are a few hydroxyl groups and few free acid molecules may present in the lipid.

Table 1. Physical constants of the liner silver grunter and other lipid samples

\begin{tabular}{|l|c|c|c|}
\hline Name of the sample & Refractive index & Specific gravity & Viscosity (mp) \\
\hline Muscle lipid of Cuttle fish & 1.4731 & 0.9735 & 320.325 \\
\hline Brain lipid of Baghda Chingri & 1.4736 & 0.941 & 303.260 \\
\hline Liver lipid of Blue Spotted Fantail Ray & 1.4760 & 0.9575 & 325.325 \\
\hline Muscle lipid of Liner silver grunter & 1.4855 & 0.934 & 297.112 \\
\hline
\end{tabular}

The moisture content of the de-oiled muscle of liner silver grunter was found to be $0.45 \%$. The moisture contents in fixed oils or fats are varies slightly and only small amount is generally present. The fiber content of de-oiled muscle of liner silver grunter was found to be $1.46 \%$. The ash content of the de-oiled muscle of liner silver grunter was found to be $0.03 \%$. The protein content of de-oiled muscle of liner silver grunter was found to be $2 \%$.

Table 2. Moisture content, fiber content, ash content and protein content of the de-oiled muscle of liner silver grunter

\begin{tabular}{|c|c|c|c|c|}
\hline Name of the sample & $\begin{array}{c}\text { Moisture content } \\
(\mathbf{\%})\end{array}$ & $\begin{array}{c}\text { Fiber content } \\
\mathbf{( \% )}\end{array}$ & $\begin{array}{c}\text { Ash } \\
\text { content } \\
(\mathbf{\%})\end{array}$ & $\begin{array}{c}\text { Protein content } \\
(\mathbf{\%})\end{array}$ \\
\hline $\begin{array}{c}\text { Muscle lipid of } \\
\text { liner silver grunter }\end{array}$ & 0.45 & 1.46 & 0.03 & 2.00 \\
\hline
\end{tabular}

\subsection{Chemical properties of the lipid sample}

The saponification value of the muscle lipid of liner silver grunter was found to be 189.62 (Table 3). The saponification equivalent value of muscle lipid of liner silver grunter was found to be 295.86. Saponification value is inversely proportional to the average molecular weight or chain length of the fatty acids present in the fat or oil. The saponification equivalent is directly proportional to the average chain length of fatty acid present. The results clearly indicate that the lipid sample contains higher proportion of high molecular weight fatty acids.

The acid value of muscle lipid of liner silver grunter was found to be 0.70 (Table 3 ). The percentage of free fatty acid (FFA), as oleic, was calculated from acid value and was found to be 0.35 (Table 3) for the muscle lipid of liner silver grunter. Acid value indicates the proportion of free fatty acid in the oil or fat. The free fatty acid is produced by the hydrolytic decomposition of the oil or fat. Thus, low acid value is an indication of freshness of the oil or fat and suitability of the lipid for edible purpose. The ester value of the muscle lipid of liner silver grunter was found to be 188.92 (Table 3). This value indicates the amount of ester present in the lipid sample.

Iodine value gives an estimation of the degree of unsaturation and so of the relative amounts of unsaturated fatty acids in the triglyceride molecules of the fat or oil. Iodine value of muscle lipid of liner silver grunter was found to be 82.68 (Table 3). The value indicates that the lipid sample contains lower to moderate proportion of unsaturated fatty acids and is of nondrying type.

The peroxide value is an indication of unsaturation present in fats and oils. The more unsaturated fats or oils absorb more oxygen, the more they form greater amounts of unstable hydroperoxides and show higher peroxide values. The peroxide value of muscle lipid of liner silver grunter was found to be 78.26 (Table 3). It can be concluded from the result that the muscle lipid under investigation contained moderate amount of unsaturated fatty acids. 
The acetyl value is a measure of hydroxylated fatty acids in a fixed oil or fat. The acetyl value of the muscle lipid of liner silver grunter was found to be $11.52 \%$ (Table 3). This result indicates low content of free hydroxyl groups present in the lipid sample.

The thiocyanogen value of the muscle lipid of liner silver grunter was found to be 52.68 (Table $3)$. This observation is in conformity with the finding that the lipid sample has moderate iodine value and peroxide value.

The titre value of the muscle lipid of liner silver grunter was found to be $25.82{ }^{\circ} \mathrm{C}$ (Table 3 ). This value indicates that the lipid sample is of fat type which supports its semisolid condition at room temperature.

The Henher value of the muscle lipid of liner silver grunter was found to be $27.72 \%$ (Table 3 ). This result indicates the presence of higher percentage of water insoluble non-volatile fatty acids in the lipid sample.

The unsaponifiable matter in the muscle lipid of liner silver grunter was found to be $0.77 \%$ (Table 3). Unsaponifiable matter is defined as those substances which are not saponified by alkali and which are soluble in ether or petroleum ether. In general, if a fixed oil or fat contains unsaponifiable matter in excess of about $2 \%$ there is reason to support adulteration. The result indicates that the lipid sample may contain a small amount of unsaponifiable matter such as sterols, vitamins A \& D, hydrocarbons, etc.

The Polenske value of the muscle lipid of liner silver grunter was found to be 14.41 (Table 3). The Polenske value represents a measure of volatile water insoluble but alcohol soluble fatty acids. The Polenske value as obtained is a support of the small amount volatile water insoluble but alcohol soluble fatty acids in the lipid sample.

The Reichert-Meissl value of the muscle lipid of liner silver grunter was found to be 0.24 (Table $3)$. Since the Reichert-Meissl value is a measure of the volatile water soluble lower fatty acids present in the fat or oil, so the lower R-M value of the lipid sample is an indication of low content of volatile water soluble fatty acids.

The Kirschner value of the muscle lipid of liner silver grunter was found to be 0.40 (Table 3 ). This result indicates the presence of trace amount of fatty acids in the Reichert-Meissl distillate which forms soluble silver salt.

The muscle lipid of liner silver grunter was found to form cloudy solution with bromine and a precipitate appeared due to the insoluble bromide during the experiment. Thus, the lipid is a marine oil (fish oil).

The muscle lipid of liner silver grunter was found to form treacle-like consistency with mercuric nitrate, $\mathrm{Hg}\left(\mathrm{NO}_{3}\right)_{2}$ solution after 24 hours during the experiment. Thus, the lipid of liner silver grunter is of non-drying type.

Semidrying oils absorb oxygen from air slowly and thicken after keeping exposed to air for some time but do not dry up. The iodine value is higher than non-drying oils; it varies between 95 and 140. The non-drying oil does not absorb oxygen, nor do they dry up to form a skin, the iodine value of the non drying oil is low, it is usually under 100. The drying oils absorb oxygen from air and dry up to hard skin. The iodine value is usually above 140 .

The amount of cholesterol in the muscle lipid of liner silver grunter was found to be $28.54 \mathrm{mg} / \mathrm{g}$. It can be suggested that the muscle lipid of liner silver grunter is more suitable for edible purpose.

The effect of storage time on the muscle lipid of liner silver grunter showed a significant variation in different values. Acid value, peroxide value increased with increasing time of storage and R-M value, thiocyanogen value, titre value and iodine value decreased with increasing time of storage. It means that the quality of the lipid deteriorated with increasing time of storage. 
Table 3. Chemical constants of muscle lipid of liner silver grunter and some related fats and oils

\begin{tabular}{|c|c|c|c|c|c|c|c|c|c|c|c|c|c|c|c|}
\hline $\begin{array}{c}\text { Name of } \\
\text { the } \\
\text { sample }\end{array}$ & S.V. & S.E.V. & A.V. & $\begin{array}{c}\text { F.F.A. } \\
(\%) \\
\text { (as } \\
\text { oleic) }\end{array}$ & E.V. & I.V. & P.O.V. & \begin{tabular}{|c|} 
Acetyl \\
Value \\
$(\%)$
\end{tabular} & T. V. & $\begin{array}{c}\text { Titre } \\
\text { value } \\
\left({ }^{\circ} \mathrm{C}\right)\end{array}$ & H.V. & $\begin{array}{c}\text { U.S.M. } \\
(\%)\end{array}$ & P.V. & R.M.V. & K.V. \\
\hline Olive oil & $\begin{array}{l}190- \\
195\end{array}$ & $\begin{array}{l}287- \\
295\end{array}$ & $\begin{array}{c}0.6- \\
1.5\end{array}$ & $\begin{array}{l}0.25- \\
0.60\end{array}$ & --- & $80-88$ & --- & 10.4 & $75-83$ & 17.26 & 0.6 & $0.5-1.2$ & 0.5 & $0.6-1.5$ & --- \\
\hline $\begin{array}{l}\text { Sunflower } \\
\text { oil }\end{array}$ & $\begin{array}{l}190- \\
194\end{array}$ & $\begin{array}{l}287- \\
295\end{array}$ & $\begin{array}{l}0.6- \\
2.4\end{array}$ & $\begin{array}{l}0.15- \\
0.45\end{array}$ & --- & $\begin{array}{l}125- \\
140\end{array}$ & --- & --- & $\begin{array}{c}78.4- \\
81.3\end{array}$ & 17 & --- & $0.3-0.9$ & --- & 0.5 & --- \\
\hline $\begin{array}{l}\text { Soyabean } \\
\text { oil }\end{array}$ & $\begin{array}{l}190- \\
195\end{array}$ & $\begin{array}{l}287- \\
295\end{array}$ & $\begin{array}{l}1.2- \\
1.5\end{array}$ & $\begin{array}{l}0.35- \\
0.85\end{array}$ & --- & $\begin{array}{l}129- \\
137\end{array}$ & --- & --- & $77-85$ & $22-27$ & --- & $0.7-1.6$ & $0.2-1$ & $\begin{array}{l}0.5- \\
2.55\end{array}$ & --- \\
\hline $\begin{array}{l}\text { Coconut } \\
\text { oil }\end{array}$ & $\begin{array}{c}255- \\
260\end{array}$ & $\begin{array}{l}210- \\
250\end{array}$ & $\begin{array}{l}2.5- \\
10.0\end{array}$ & --- & --- & $\begin{array}{l}8.2- \\
9.6\end{array}$ & --- & --- & $\begin{array}{l}6.1- \\
7.0\end{array}$ & $20-24$ & 82 & $\begin{array}{c}0.15- \\
0.7\end{array}$ & $15-17$ & $7.8-8.0$ & --- \\
\hline $\begin{array}{l}\text { Palm- } \\
\text { Kernel oil }\end{array}$ & 248 & $\begin{array}{l}220- \\
250\end{array}$ & $\begin{array}{c}220- \\
250\end{array}$ & --- & --- & 15-18 & --- & --- & --- & --- & 94.2 & --- & --- & 28 & --- \\
\hline $\begin{array}{l}\text { Sardine } \\
\text { oil }\end{array}$ & $\begin{array}{l}189.8- \\
193.8\end{array}$ & --- & $\begin{array}{l}2.2- \\
21.7\end{array}$ & --- & --- & $\begin{array}{l}138- \\
177\end{array}$ & --- & --- & --- & --- & --- & --- & --- & --- & --- \\
\hline Whale oil & $\begin{array}{l}184- \\
200\end{array}$ & --- & $\begin{array}{c}0.3- \\
51\end{array}$ & --- & --- & 126.9 & --- & --- & --- & --- & --- & --- & --- & --- & --- \\
\hline $\begin{array}{l}\text { Muscle } \\
\text { lipid of } \\
\text { Hilsa }\end{array}$ & 203.25 & 276.01 & 3.108 & 1.56 & --- & 92.55 & 55.05 & 10.255 & 52.54 & --- & 93.27 & 0.74 & 0.764 & 0.965 & --- \\
\hline $\begin{array}{l}\text { Muscle } \\
\text { lipid of } \\
\text { Flathead } \\
\text { mullet }\end{array}$ & 182.5 & 307.397 & 2.83 & 1.26 & -- & 125.92 & -- & 11.22 & 68.09 & 26.60 & 79 & 1.16 & 0.36 & 0.92 & --- \\
\hline $\begin{array}{l}\text { Muscle } \\
\text { lipid of } \\
\text { Cuttle } \\
\text { fish }\end{array}$ & 260.87 & 215.05 & 1.78 & 0.89 & 258.77 & 106.82 & 109.45 & 12.95 & 54.82 & 27.5 & 77.98 & 1.10 & 0.72 & 0.91 & 0.424 \\
\hline $\begin{array}{l}\text { Muscle } \\
\text { lipid of } \\
\text { liner } \\
\text { silver } \\
\text { grunter }\end{array}$ & 189.62 & 295.86 & 0.70 & 0.35 & 188.92 & 82.68 & 78.26 & 11.52 & 52.68 & 25.82 & 27.72 & 0.77 & 14.41 & 0.24 & 0.40 \\
\hline
\end{tabular}

Abbreviations: S.V.= Saponification Value; S.E.V.= Saponification Equivalent Value; A.V.= Acid Value; F.F.A.= Free Fatty Acid; E.V.= Ester Value; I.V.= Iodine Value; P.O.V.= Peroxide Value; T.V.= Thiocyanogen Value; H.V.= Henher Value; U.S.M.= Unsaponifiable Matter; P.V.= Polenske Value; R.M.V.= Reichert-Meissl Value; K.V.= Kirschner Value.

"--" = Data not available.

\section{3 Chromatographic examination of muscle lipid of liner silver grunter}

\subsubsection{TLC Analysis}

The muscle lipid of liner silver grunter was subjected to TLC examination and its fatty acid composition was identified by comparing the $\mathrm{R}_{\mathrm{f}}$ values of different spots of chromatograms with those of standard fatty acids as reported (Table 4) in different solvent systems. From the chromatogram three spots were identified as palmitic acid $\left(\mathrm{C}_{16: 0}\right)$, stearic acid $\left(\mathrm{C}_{18: 0}\right)$ and oleic acid $\left(\mathrm{C}_{18: 1}\right)$ in the muscle lipid of liner silver grunter.

\subsubsection{GLC Analysis}

The chromatographic method especially gas liquid chromatography (GLC) radically changed the possibilities for obtaining compositional data from biological material. The continuous increase in the refinement and exactness of the chromatographic separations has made them a powerful analytical tool. Their simplicity together with their rapidness has resulted in the availability of extensive compositional data of fatty acid composition of lipids. Identification and qualification of fatty acids in the lipid sample was determined by GLC as shown in Table 5. 
Table 4. The $\mathrm{R}_{\mathrm{f}}$ values (most related) of thin layer chromatographic examination of the muscle lipid of liner silver grunter

\begin{tabular}{|c|c|c|c|c|c|c|c|c|c|}
\hline \multirow[t]{2}{*}{ Solvent system } & \multicolumn{5}{|c|}{$\mathrm{R}_{\mathrm{f}}$ values of standard fatty acids } & \multicolumn{4}{|c|}{$\begin{array}{c}\mathrm{R}_{\mathrm{f}} \text { values obtained from the spots } \\
\text { of lipid sample }\end{array}$} \\
\hline & PA & SA & $\mathrm{OA}$ & LA & EA & & & & \\
\hline $\mathrm{P}: \mathrm{E}: \mathrm{A}(70: 30: 1)$ & 0.942 & 0.961 & 0.417 & --- & --- & 0.475 & 0.796 & 0.943 & -- \\
\hline $\begin{array}{l}P: E \\
(80: 20)\end{array}$ & 0.941 & 0.943 & 0.287 & 0.933 & 0.361 & 0.286 & 0.646 & 0.769 & 0.815 \\
\hline $\begin{array}{l}\mathrm{P}: \mathrm{H} \\
(80: 20)\end{array}$ & 0.813 & 0.832 & 0.316 & --- & --- & 0.323 & 0.846 & 0.923 & -- \\
\hline $\begin{array}{l}\mathrm{H}: \mathrm{E} \\
(80: 20)\end{array}$ & 0.815 & 0.820 & 0.201 & 0.641 & 0.201 & 0.821 & --- & --- & --- \\
\hline
\end{tabular}

PA- Palmitic Acid, SA-Stearic Acid, OA- Oleic Acid, LA-Linoleic Acid, EA- Erucic Acid

$\mathrm{P}: \mathrm{E}: \mathrm{A}=$ Petroleum ether:Ether:Acetic Acid; P:E = Petroleum ether:Ether; $\mathrm{P}: \mathrm{H}=$ Petroleum ether:Hexane; H:E = Hexane:Ether

\subsection{Estimation of minerals}

Most of the people of our country have been suffering from protein malnutrition. From the Table 6 , it is evident that liner silver grunter $(0.320 \%)$ contained good amount of nitrogen as well as protein (proteineous nitrogen) which are well balanced in respect of essential amino acids. The percentage of phosphorus in the muscle of liner silver grunter was 0.313 . The result indicates that phospholipids may present in the lipid which was extracted from the muscle of fish sample. The percentage of potassium in the muscle of liner silver grunter was found to be 0.013 . Consumption of this marine species may be helpful to increase blood pressure for those people having low blood pressure. So, this may be a remedy of low blood pressure. The percentage of sodium in muscle of liner silver grunter was found to be 0.16 . Above all, maximum catch and use of liner silver grunter should be encouraged for their ready supply to different remote regions under careful processing to avoid putrefaction.

Table 5. Fatty acid composition of the fatty acid methyl ester mixture derived from the lipid of liner silver grunter

\begin{tabular}{|l|l|c|c|l|c|}
\hline $\begin{array}{c}\text { SI } \\
\text { No. }\end{array}$ & \multicolumn{1}{|c|}{ Name of fatty acid } & $\begin{array}{c}\text { Relative } \\
\text { percentage } \\
(\%)\end{array}$ & $\begin{array}{c}\text { SI } \\
\text { No. }\end{array}$ & \multicolumn{1}{|c|}{ Name of fatty acid } & $\begin{array}{c}\text { Relative } \\
\text { percentage } \\
(\%)\end{array}$ \\
\hline 1 & Lauric Acid (C12:0) & --- & 15 & Linolenic Acid (C18:3) & 2.5874 \\
\hline 2 & Myristic Acid (C14:0) & 7.3572 & 16 & Arachidic Acid (C20:0) & 0.1435 \\
\hline 3 & Myristoleic Acid (C14:1) & --- & 17 & Eicosenoic Acid (C20:1) & 0.3222 \\
\hline 4 & Pentadecyclic Acid (C15:0) & 0.3945 & 18 & Eicosadienoic Acid (C20:2) & 0.7478 \\
\hline 5 & Palmitic Acid (C16:0) & 24.1403 & 19 & Eicosatrienoic Acid (C20:3) & 0.0772 \\
\hline 6 & Palmitoleic Acid (C16:1) & 14.2523 & 20 & Arachidonic Acid (C20:4) & 1.4553 \\
\hline 7 & Hexadecadieonic Acid (C16:2) & 1.9748 & 21 & $\begin{array}{l}\text { Eicosapentanoic Acid (EPA) } \\
\text { (C20:5) }\end{array}$ & 12.7467 \\
\hline 8 & $\begin{array}{l}\text { Hexadecatrieonic Acid (HTA) } \\
\text { (C16:3) }\end{array}$ & 2.2677 & 22 & Behenic Acid (C22:0) & --- \\
\hline 9 & Margaric Acid (C17:0) & --- & 23 & Erucic Acid (C22:1) & --- \\
\hline 10 & Heptadecenoic Acid (C17:1) & --- & 24 & Docosadienoic Acid (C22:2) & 0.4978 \\
\hline 11 & Stearic Acid (C18:0) & 6.1787 & 25 & Docosatrienoic Acid (C22:3) & 0.2131 \\
\hline 12 & Oleic Acid (C18:1) & 9.2587 & 26 & Adrenic Acid (C22:4) & 3.2656 \\
\hline 13 & Vaccenic Acid (C18:1) & 5.4831 & 27 & $\begin{array}{l}\text { Docosapentanoic Acid (DPA) } \\
\text { (C22:5) }\end{array}$ & 4.8355 \\
\hline 14 & Linoleic Acid (C18:2) & 1.7797 & 28 & $\begin{array}{l}\text { Docosahexanoic Acid (DHA) } \\
\text { (C22:6) }\end{array}$ & 0.0209 \\
\hline
\end{tabular}




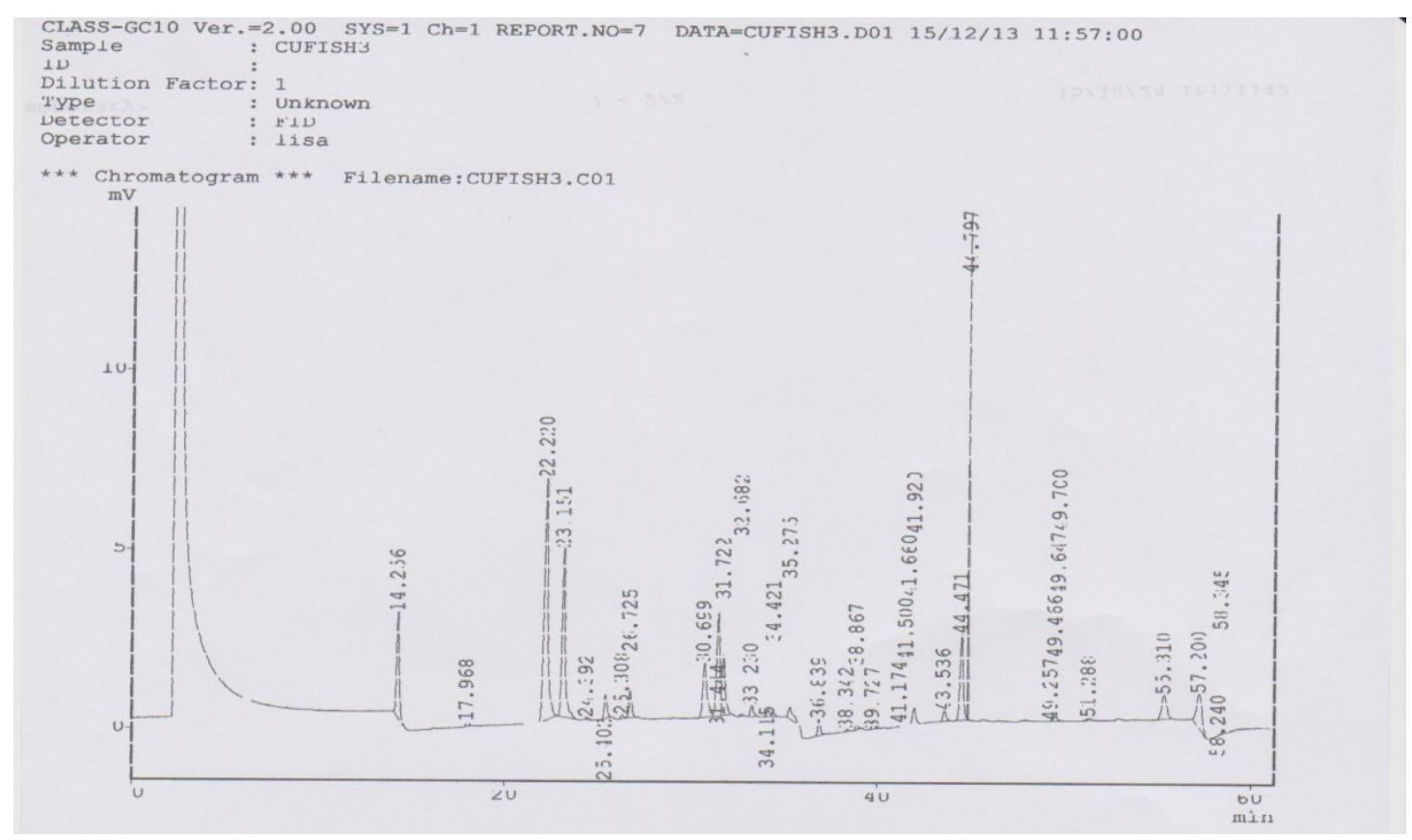

Figure 2. GLC analysis of liner silver grunter

Table 6. Percent of $\mathrm{N}, \mathrm{P}, \mathrm{K}, \mathrm{Na}$ and $\mathrm{Ca}$ in muscle of liner silver grunter

\begin{tabular}{|l|c|c|c|c|c|}
\hline Name of the sample & N (\%) & P (\%) & K (\%) & $\begin{array}{c}\text { \% of Na } \\
(\%)\end{array}$ & Ca (\%) \\
\hline Muscle lipid of Cuttle fish & 6.533 & 1.2374 & 1.118 & -- & 0.798 \\
\hline Brain lipid of Baghda Chingri & 3.540 & 0.7262 & 1.123 & -- & 0.914 \\
\hline Liver lipid of Blue Spotted Fantail Ray & 4.099 & 2.7500 & 1.180 & -- & 0.641 \\
\hline Muscle lipid of liner silver grunter & 0.320 & 0.313 & 0.013 & 0.16 & -- \\
\hline
\end{tabular}

'--' indicates data not available.

\subsection{Metal analysis of lipid containing muscle of liner silver grunter}

From the Table 7, it is evident that iron (Fe) content of muscle of liner silver grunter was 9.28 ppm. Iron is a constituent of hemoglobin, catalase, ferredoxin etc. and acts as a co-factor for several enzymes. The Fe deficiency in human body causes anemia, hypo chromic demand's etc. By eating different iron rich food we can fulfill the demand of Fe. The fish may be a good source of Fe.

Copper $(\mathrm{Cu})$ content of muscle of liner silver grunter was $3.98 \mathrm{ppm}$. $\mathrm{Cu}$ is an essential mineral of human body. As $\mathrm{Cu}$ plays an important role in enzyme action maturation of elastic and fish is a good source of $\mathrm{Cu}$, we can take the fish more and more. Zinc ( $\mathrm{Zn})$ content of muscle of fish sample was $4.22 \mathrm{ppm}$.

The manganese (Mn) content of muscle lipid of fish sample was $0.39 \mathrm{ppm}$. The arsenic (As) content of liner silver grunter was $0.35 \mathrm{ppm}$. It can be concluded from the finding that the amount of As is not above the danger level. Hence, the people can easily take or eat the fish without any fear or hesitation of As poisoning.

The magnesium $(\mathrm{Mg})$ of muscle of fish sample was $56.27 \mathrm{ppm}$. The level is far below the limit for fish propod by World Health Organization and safe within the limits for human consumption in the edible part of the studied fish.

It is to be mentioned here that cobalt $(\mathrm{Co})$, cadmium $(\mathrm{Cd})$, chromium $(\mathrm{Cr})$, nickel $(\mathrm{Ni})$ and lead $(\mathrm{Pb})$ were not found in the muscle of fish sample. 
Table 7. Concentration of different metals in muscle lipid of liner silver grunter

\begin{tabular}{|c|c|}
\hline Metals & Concentration (ppm) \\
\hline $\mathrm{Fe}$ & 9.28 \\
\hline $\mathrm{Co}$ & - \\
\hline $\mathrm{Cu}$ & 3.98 \\
\hline $\mathrm{Cr}$ & - \\
\hline $\mathrm{Zn}$ & 4.22 \\
\hline $\mathrm{Cd}$ & - \\
\hline $\mathrm{Ni}$ & - \\
\hline $\mathrm{Pb}$ & - \\
\hline $\mathrm{Mn}$ & 0.39 \\
\hline $\mathrm{As}$ & 0.35 \\
\hline $\mathrm{Mg}$ & 56.27 \\
\hline '-' means that the metal was not found in muscle of liner silver grunter
\end{tabular}

\subsection{Antibacterial and antifungal activities of the lipid sample}

In the present study, the muscle lipid of liner silver grunter was selected and screened for antibacterial activities against nine bacteria and antifungal activities against seven phyto pathogenic fungi.

\subsubsection{Antibacterial test}

To examine the antibacterial activities of the lipid sample, it was subjected to antibiosis test against several bacteria such as Salmonella sp., Shigella sp., Lactobacillus casei, Proteus vulgaris, Escherichia coli, Staphylococcus aureus, Klebsiella pneumonia, Bacillus cereus, Pseudomonas sp. For the test, chloroform was used as a solvent to prepare desired solution (10\%) of the lipid sample. The lipid sample did not exhibit activity against any of the bacteria tested under the specified conditions. So, it may be said that the sample does not have any activity against the above mentioned bacteria.

\subsubsection{Antifungal activities}

The antifungal activities of the lipid sample were studied against seven phyto-pathogenic fungi. It is evident that the muscle lipid of liner silver grunter showed very lower zone of inhibition on mycelial growth of Fusarium equiseti, Aspergillus fumigateus, Alternaria alternata, Curvularia lunata, Collectortrichum sp., Asperigillus flavus and Asperigillus ochraceus respectively which is not meaningful.

\section{Conclusions}

Physico-chemical characterization and microbial studies of muscle lipid of Liner silver grunter (Pomadasys hasta) was performed in the current research work. The presence of moderate amount of unsaturated fatty acids in the lipid sample was confirmed by R.I., S.V., I.V. and T.V. Low content of volatile water-soluble and volatile water-insoluble fatty acids was established by R.M.V. and P.V. Low free hydroxyl group content was confirmed by the acetyl value of the lipid sample. Percentage of F.F.A. validated suitability of the oil for edible purpose. Non drying nature of the muscle lipid of liner silver grunter was pointed out by I.V. and confirmed by Elaiden test. Chromatographic examinations (TLC and GLC) substantiated the presence of some important fatty acids in the lipid sample. After determining the metal contents of the muscle of the fish sample, it can be said that the levels of metals in the fish sample are below the limit for fish proposed by World Health Organization and safe within the limits for human consumption in the edible part of the studied fish. However, no decisive conclusion could be drawn from antimicrobial screening results with the lipid sample. 


\section{Acknowledgment}

The authors are highly indebted to Mr. Mohammad Wahidul Alam, Assistant Professor, Institute of Marine Sciences and Fisheries, University of Chittagong and Mr. Rajib Acharjee, Assistant Professor, Department of Zoology, University of Chittagong for identifying the marine species and their thoughtful suggestions during this work.

\section{References}

[1] M. Begum et al., A comparative microbiological assessment of five types of selected fishes collected from two different markets, J. Advan. Biol. Res. 4 (2010) 259-265.

[2] R.G. Ackman, Perspectives on Eicosapentaenoic Acid (EPA), n-3 News, Massachusetts General Hospital, Boston. 1(4) (1986) 1-4.

[3] W.E.M. Lands, Fish and Human Health, Academic Press, London, 1986.

[4] R.G. Ackman, Fatty Acid Composition of Fish Oils, Nutritional Evaluation of Long Chain Fatty Acids in Fish Oil, Edited by SM. Barlow and ME Stansby, Academic Press, London, 1982, pp. 25-88.

[5] A.K.A. Rahman, Freshwater Fishes of Bangladesh, $2^{\text {nd }}$ Edition, Zoological Society of Bangladesh, Dhaka, 2005.

[6] Kamal Uddin Siddiqui et al., Encyclopedia of Flora and Fauna of Bangladesh Marine fishes, Asiatic Society of Bangladesh, Dhaka, 24, 2009.

[7] M.H. Uddin, M.A. Majid, Physico-chemical characterization and study of microbial activities of the brain lipid and chemical analysis of the brain of Kerani Chingri (Metapenaeus affinis) of the Bay of Bengal, Chittagong Univ. J. Sc. 24 (2000) 83-89.

[8] A.I. Vogel, A Text Book of Practical Organic Chemistry, Addission Wesley Longman Ltd, London, 1975.

[9] M.H. Uddin et al., Isolation, Characterization and Study of the Microbial Activities of the Brain Lipid and Chemical Analysis of the Brain of Baghda Chingri (Penaeus monodon) of the Bay of Bengal, Pak. J. Sc. Ind. Res. 41 (2004) 121-125.

[10] S. Ranganna, Handbook of Analysis and Quality Control for Fruit and vegetable Products, 2nd Edn., Tata McGraw-Hill Publishing Company Ltd., New Delhi, India, 1991.

[11] A.J. Marshall, W.D. Williams, Textbook of Zoology Invertebrate, Edn. 7, 1995.

[12] R.C. Griffin, Technical Method of Analysis, 2nd Edn., McGraw-Hill Book Company, Inc., New York, 1972.

[13] B.J. Morris, The Chemical Analysis of Foods and food Products, D. Van Nostrand Company, Inc., New York, 1965.

[14] S. Ranganna, Handbook of Analysis and Quality Control for Fruit and vegetable Products, 2nd Edn., Tata McGraw-Hill Publishing Company Ltd., New Delhi, India, 1991.

[15] R.K. Das, Industrial Chemistry, Part II, Kalyani Publishers, New Delhi, India, 1989.

[16] K.A. Williams, Oils, Fats and Fatty Foods, 4th Edn., J. \& A. Churchill Ltd, 1966.

[17] M. Loury, Study of fats and lipids by thin-layer chromatography, Rev. Franc. Corps. Gras. 11 (1966) 259-272.

[18] E.C. Horwing et al., Quantitative analysis of fatty acids by gas-liquid chromatography, J. Lipid Research. 5(1) (1964) 20-27. 
[19] A.P. Kenny, The determination of cholesterol by the Liebermann-Burchard reaction. Biochemical Journal. 52(4) (1952) 611-619.

[20] M. Al-Amin et al., Extraction, Physico-Chemical Characterization and Antimicrobial Screening of the Muscle Lipid of Cuttle Fish (Sepia esculenta) of the Bay of Bengal, Int. Lett. Chem. Phy. Astr. 17 (2014) 87-97.

[21] J. Basett et al., Vogel's Textbook of Quantitative Chemicals Analysis, 5th edition, Longman Group UK Ltd., 1989.

[22] J. Basett, R.C. Denney, G.H. Heffery, J. Mendham, Vogel's Textbook of Quantitative inorganic Analysis, $4^{\text {th }}$ edition, Longman Group UK Ltd., 1978.

[23] I.M.M. Rahman et al., Analytical Characterization and Antimimicrobial Screening of the Hilsha (Tenualosa ilisha) Fish Lipid from the Bay of Bengal, Hamdard Medicus. 52(3) (2009) 23-28. 